\title{
CONTAMINANT TRANSPORT IN TWO CENTRAL MISSOURI KARST RECHARGE AREAS
}

\author{
R.N. LERCH \\ USDA-Agricultural Research Service, Cropping Systems and Water Quality Research Unit, 269 Agricultural Engineering Bldg., University of Missouri, \\ Columbia, MO 65211, bob.lerch@ars.usda.gov
}

\begin{abstract}
Karst watersheds with significant losing streams represent a particularly vulnerable setting for groundwater contamination because of the direct connection to surface water. Because of the existing agricultural land-use and future likelihood of urbanization, two losing-stream karst basins were chosen for intensive monitoring in Boone County, Missouri: Hunters Cave and Devils Icebox. Both caves were formed in Burlington Limestone and have similar recharge areas $\left(33\right.$ to $\left.34 \mathrm{~km}^{2}\right)$ and land uses. Year-round monitoring was conducted from April 1999 through March 2002 to characterize the water quality of the main cave streams relative to herbicide, nutrient, and sediment contamination. Water sampling entailed grab samples at regular intervals and runoff-event samples collected using automated sampling equipment. Total nitrogen, phosphorus, and sediment concentrations and loads were consistently higher in the Devils Icebox stream compared to Hunters Cave. Median total $\mathrm{N}$ fluxes were $96 \mathrm{~g} \mathrm{~km}^{-2} \mathrm{~d}^{-1}$ at Devils Icebox and $30 \mathrm{~g} \mathrm{~km}^{-2} \mathrm{~d}^{-1}$ at Hunters Cave, while median total $P$ fluxes were $8.5 \mathrm{~g} \mathrm{~km}^{-2} \mathrm{~d}^{-1}$ at Devils Icebox and $3.3 \mathrm{~g} \mathrm{~km}^{-2} \mathrm{~d}^{-1}$ at Hunters Cave. Herbicides or their metabolites were detected in more than $80 \%$ of the samples from both cave streams, and herbicide concentrations and areal loss rates were generally similar between the sites. Overall, the greater loads and mass flux of contaminants in the Devils Icebox recharge area compared to Hunters Cave was a result of both greater stream discharge and the occurrence of more cropped fields (94\%) on claypan soils with high runoff potential. These claypan soils are known to be especially problematic with respect to surface transport of contaminants. Prevailing land use has significantly degraded the water quality in both recharge areas, but a watershed plan has been developed for the Bonne Femme watershed, which encompasses these two recharge areas. With the baseline data collected in this study, the impact of changing land uses and the implementation of management practices or new ordinances designed to improve water quality can be documented.
\end{abstract}

\section{INTRODUCTION}

The vulnerability of groundwater to contamination in karst recharge areas has been well established over the last 25 years (Hallberg et al., 1985; Boyer and Pasquarell, 1996; Younos et al., 2001; Vesper et al., 2001; Boyer, 2005), prompting the development of new methods to assess the vulnerability of karst aquifers (Gogu and Dassargues, 2000; Andreo et al., 2006). Contaminants such as nutrients (Hallberg et al., 1985; Boyer and Pasquarell, 1995; Currens, 2002; Panno and Kelly, 2004; Crain, 2006), pesticides (Pasquarell and Boyer, 1996; Currens, 2002; Panno and Kelly, 2004; Crain, 2006), sediment (Hallberg et al., 1985; Mahler et al., 1999; Crain, 2006), heavy metals (Vesper and White, 2003; Vesper et al., 2001), organic solvents (Loop and White, 2001; Vesper et al., 2001), petroleum products (Ruhe et al., 1980), fecal bacteria (Pasquarell and Boyer, 1995; Lerch et al., 2002; Pronk et al., 2006), and endocrine disruptors (Wicks et al., 2004) have been documented in karst aquifers. These contaminants may be harmful to humans exposed through drinking water obtained from karst aquifers and through recreational activities in caves. The establishment of maximum contaminant levels for drinking water (USEPA, 1996) and whole-body contact standards for fecal coliforms (e.g., USEPA, 2002) reflect the health concerns associated with exposure to these contaminants. In addition, cave-adapted organisms (i.e., stygobites and troglobites) may also be harmed by the presence of these contaminants in cave streams and drip waters (Elliott, 2000; Taylor et al., 2000; Spanjer and Cipollini, 2006), leading to disruption of karst ecosystems.

The wide array of contaminants impacting karst aquifers indicates that private on-site sewer systems and land uses such as urban development, agricultural production, industrial production, and military activities are all potential threats to groundwater quality. It is now well accepted that surface land uses directly impact the water quality of karst aquifers, especially those with discrete, or allogenic, recharge mechanisms (Betson, 1977; Ruhe et al.,

Disclaimer: Mention of specific companies, products, or trade names is made only to provide information to the reader and does not constitute endorsement by the USDA-Agricultural Research Service. 
1980; Boyer and Pasquarell, 1994; Currens, 2002; Panno and Kelly, 2004; Lerch et al., 2005). In southeastern West Virginia, Boyer and Pasquarell (1994) found strong linear relationships between the percentage of a karst recharge area in agricultural use with the concentrations of nitrate$\mathrm{N}$, fecal coliforms, and triazine herbicides. In urban areas, the impact of increased impervious surfaces on allogenically recharged karst aquifers has been shown to be very similar to that on surface streams (Booth et al., 2002), resulting in greater discharge velocity, peak discharge, and volume of storm-water runoff (Betson, 1977; Ruhe et al., 1980). These hydrologic impacts have led to the development of strategies for managing urban growth to protect karst-water resources (Butler, 1987; Frueh et al., 2008).

Within central Missouri, the recharge area of the Devils Icebox has been extensively studied (St. Ivany, 1988; Halihan et al., 1998; Wicks, 1997; Wicks and Engeln, 1997; Lerch et al., 2005; Dogwiler et al., 2007), but the recharge area of nearby Hunters Cave was only recently documented (Lerch et al., 2005). The two recharge areas are located within the Bonne Femme Creek watershed located due south of Columbia (Fig. 1). The Devils Icebox recharge area is approximately $34.0 \mathrm{~km}^{2}$, and it is composed of two distinct parts, an allogenic recharge area, corresponding to upper Bonne Femme Creek, and a discrete recharge area, encompassing the Pierpont sinkhole plain (Fig. 1) (Lerch et al., 2005). The majority of the streamflow in Devils Icebox derives from the allogenic portion of the recharge area. The Hunters Cave recharge area encompasses approximately $33.3 \mathrm{~km}^{2}$, and its recharge is predominantly allogenic, occurring through a fault conduit connecting two tributaries of Turkey Creek to the uppermost part of the cave stream and a conduit connecting Bass Creek to the lower portion of the cave (Fig. 2). Both cave streams show rapid response to precipitation, and the resurgences have large variations in discharge (Wicks, 1997; Halihan et al., 1998; Lerch et al., 2005).

Although a number of studies have measured water quality or quantity in karst aquifers (Hallberg et al., 1985; Boyer and Pasquarell, 1995; Currens, 2002; Wicks et al., 2004; Panno and Kelly, 2004; Dogwiler et al., 2007), few studies to date have intensively monitored both water quantity and quality for a broad range of agricultural contaminants over multiple years. Thus, data on contaminant loads and their seasonality are lacking in the literature. Documenting current loads is critical for establishing baseline conditions so that the effects of future changes in land use on water quality and quantity can be assessed. Furthermore, load data are crucial for evaluating the effectiveness of management practices or growthmanagement strategies that may be implemented in karst aquifers for the purpose of improving or protecting water quality (Frueh et al., 2008). Frequent monitoring over multiple years also provides a more accurate assessment of the range of contaminant concentrations present in the aquifer, especially for contaminants with seasonal inputs and limited environmental persistence such as herbicides. This information is essential for accurately assessing the potential toxicity of contaminants on karst ecosystems.

The study presented here was conducted to assess the transport of agricultural contaminants within the Devils Icebox and Hunters Cave recharge areas. The Bonne Femme watershed at present is predominantly agricultural, but it is rapidly urbanizing due to growth of the cities of Ashland and Columbia. This study was initiated before significant changes in urban development and impervious surface occurred so that the effect of changing land use on the quality and quantity of water in these two karst recharge areas could be evaluated in the future. The objectives of this study were to characterize the concentrations and determine the loads of sediment, nutrients, and commonly used soil-applied herbicides in the Devils Icebox and Hunters Cave recharge areas by intensive monitoring of the resurgences of both caves.

\section{Materials ANd Methods}

\section{Site Descriptions and Land Use}

The caves were formed in the Burlington Limestone (Osagean Series, Mississippian System) (Wicks, 1997). The upper (eastern) portions of both recharge areas are covered by clay-rich Pleistocene glacial and loess deposits (St. Ivany, 1988). These low-permeability, fertile soils are generally in the Mexico-Putnam or Mexico-Leonard soil associations (USDA-NRCS, 2001). The lower (western) portions of each recharge area are characterized by residual soils of the Weller-Bardley-Clinkenbeard association and are the areas with karst features, including the two cave entrances. Both caves exhibit rudimentary branching patterns, with smaller side passages that are tributaries to the primary cave streams (Fig. 3). Devils Icebox is currently listed as Missouri's seventh longest cave, at $10.76 \mathrm{~km}$ (Gulden, 2010). The main trunk passage is the primary stream conduit, and it extends for approximately $6.4 \mathrm{~km}$ before reaching a sump. The cave system's downstream end is a spring located in Rock Bridge Memorial State Park. The length of Hunters Cave is $2.54 \mathrm{~km}$, which currently makes it the $36^{\text {th }}$ longest cave in Missouri. The main passage is also the primary stream conduit, and it extends for approximately $1.25 \mathrm{~km}$ before reaching a sump. The spring resurgence discharges directly into Bass Creek within the Three Creeks Conservation Area. Additional details about these sites can be found in Lerch et al. (2005).

Land-use information for the major classes of forest, urban, impervious, cropland, grasslands, wetlands, and open water was obtained from $30 \mathrm{~m}$ resolution Landsat imagery data collected from 2000 to 2004. The data were classified by the Missouri Resource Assessment Partnership, and files for Boone and Audrain Counties were downloaded from the Missouri Spatial Data Information 


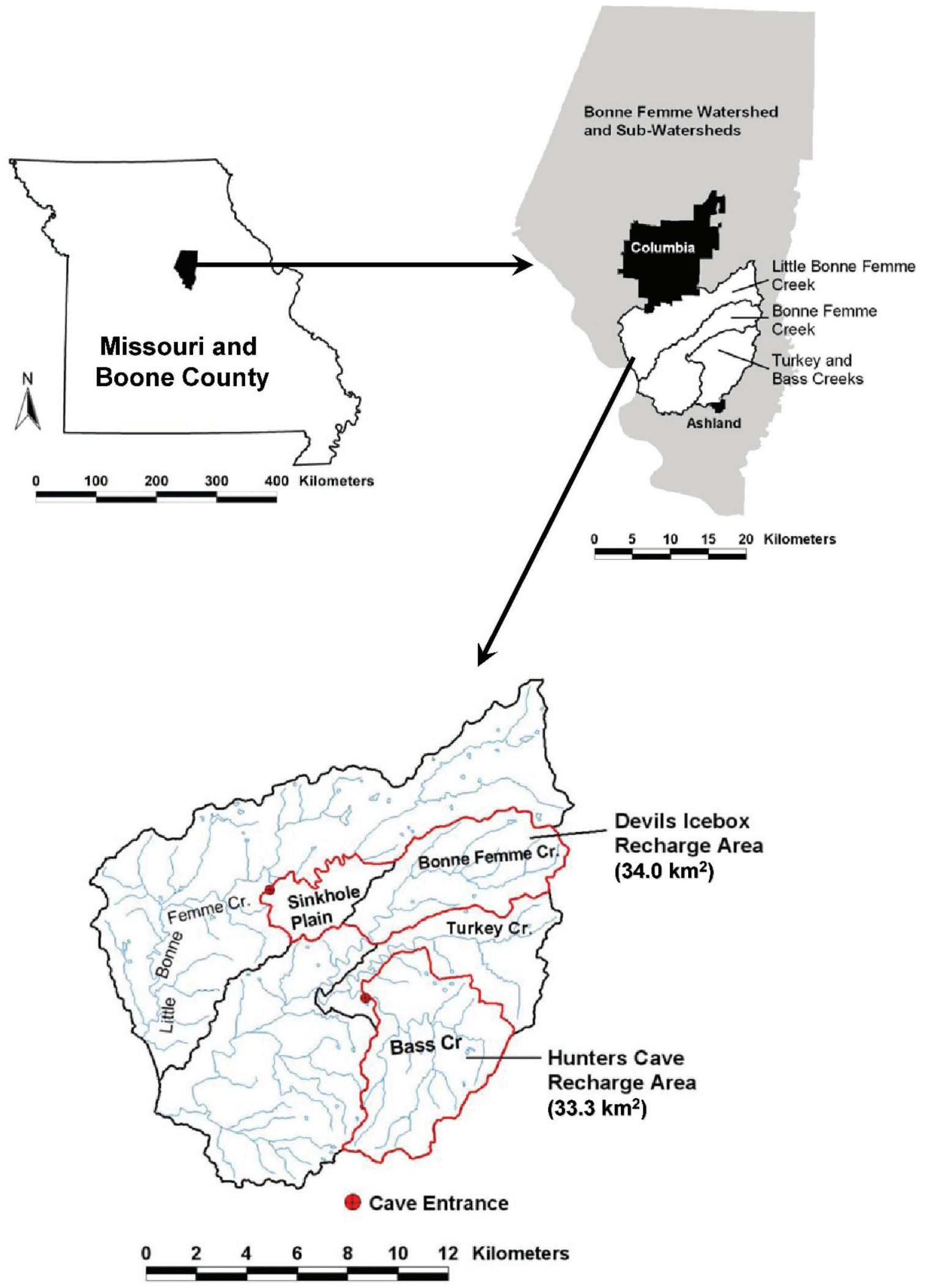

Figure 1. Location and hydrologic setting of the two karst recharge areas. 


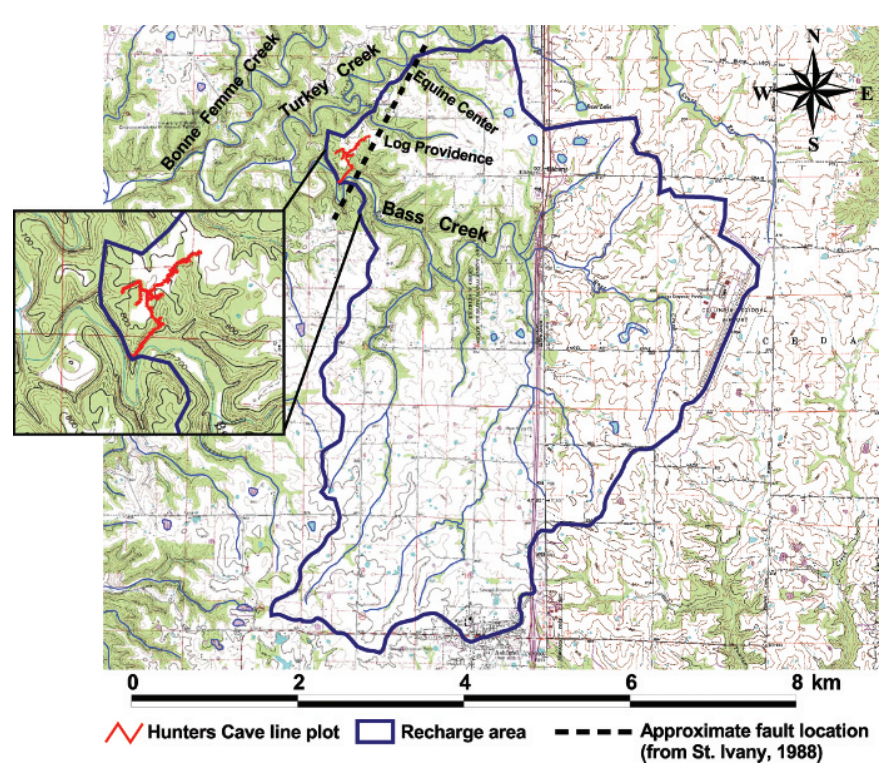

Figure 2. Hunters Cave recharge area delineation. Inset shows the meander cut-off created by the flow path from Bass Creek to the cave stream via Angel Spring. The fault shown indicates the likely conduit from the Turkey Creek tributaries to the upper cave stream.

Service (2005). Because of their close proximity and similarity in geology and soils, both recharge areas have similar land use and cover, with about $80 \%$ of the recharge areas composed of grasslands or row crops (Fig. 4). However, the Hunters Cave recharge area had a higher proportion of grasslands and a lower proportion of row crops than Devils Icebox. Row crops within the Devils Icebox recharge area were mainly concentrated within the upper Bonne Femme watershed, while row crops within the Hunters Cave recharge area were more evenly distributed (Fig. 4). In both recharge areas, row crops were predominantly corn and soybeans. Grasslands were utilized for hay production and as range land, with cattle and horses the predominant livestock. The percentage of forest was nearly identical within both recharge areas. The Hunters Cave recharge area has a small amount of urban impervious cover at the Columbia Regional Airport in its eastern part and in commercial and residential developments in Ashland. The Devils Icebox recharge area currently has no significant amounts of either urban impervious or urban vegetation cover, and residential areas were limited to low-density developments not detected using the $30 \mathrm{~m}$ resolution data.

Crop-specific data for the herbicides monitored (see Analytical Procedures) were estimated for 1999 to 2001 growing seasons using the approach of Lerch and Blanchard (2003). The fraction of row crops in corn, soybeans, and sorghum for Boone County were calculated from data available at USDA's National Agricultural Statistics Service (USDA-NASS, no date). Multiplying this
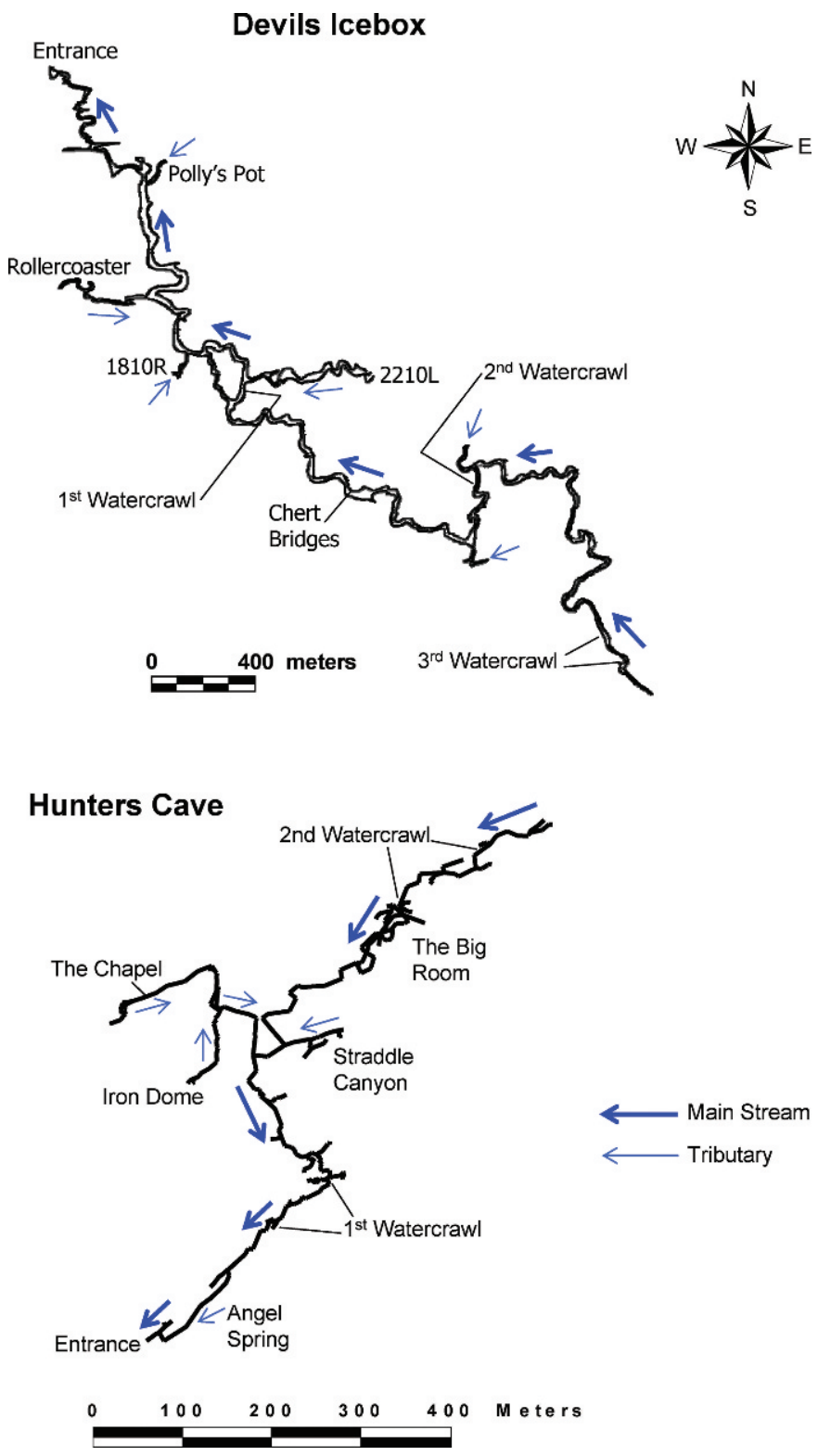

Figure 3. Line plot diagrams of the two cave systems. (Note the difference in scale for the two caves.).

fraction by the row-crop areas from the Landsat data provided an estimate of the corn, soybeans, and sorghum areas within each recharge area. This approach assumes that the proportions of specific crops in all of Boone County was applicable to the two recharge areas. Data from statewide farmer surveys were obtained from the USDA-NASS (2000-2002), including the fraction of each crop treated with a given herbicide and the average application rate. Estimates of the treated areas and total input mass for each herbicide were calculated using this information. This allowed for reporting of the herbicide losses on a treated-area basis, rather than on the basis of the entire recharge area, since herbicides were only used on row crops. 


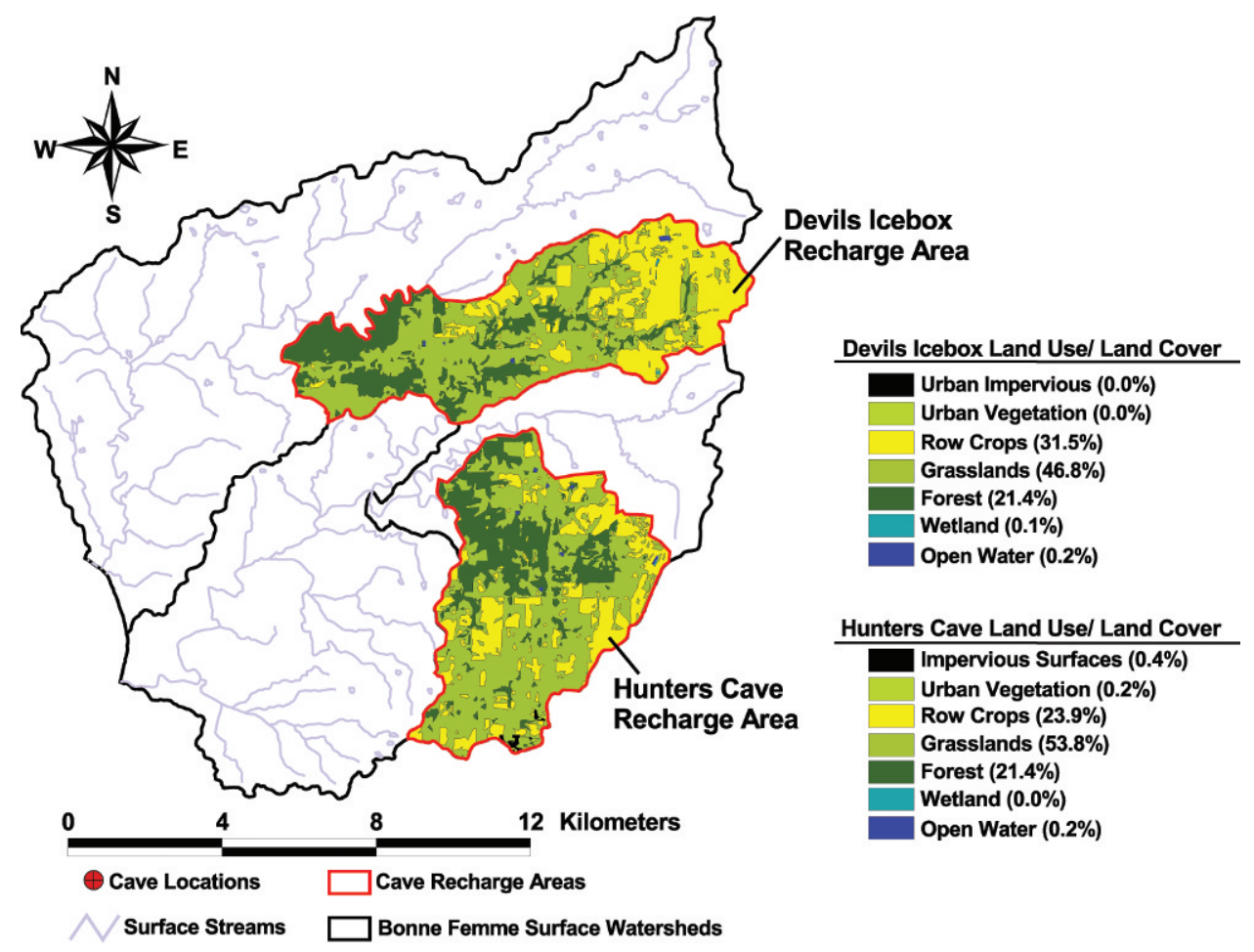

Figure 4. Land use-land cover for Devils Icebox and Hunters Cave recharge areas.

\section{Monitoring Procedures}

Hydrological, chemical, and physical monitoring of the water was conducted near the resurgence of each cave from April 1999 to March 2002. The Devils Icebox monitoring station was located within a large karst window approximately $30 \mathrm{~m}$ downstream of the resurgence (Halihan et al., 1998). The Hunters Cave monitoring station was located approximately $15 \mathrm{~m}$ into the cave (i.e., upstream of the resurgence). All instrumentation was placed in stilling wells for protection against turbulent flow and to reduce data variability. Hydrological monitoring consisted of measuring stage height at 5-minute intervals with submerged pressure-transducer probes (Global Waters Instrumentation, Inc., Gold River, California, and Hach Co., Loveland, Colorado). Stage height was then used to compute stream discharge, as detailed in Lerch et al. (2005). Turbidity was measured at 15 -minute intervals using YSI 6920 Sondes (YSI, Inc., Yellow Springs, Ohio) and expressed as nephelometric turbidity units (NTU). The turbidity probes were cleaned and calibrated every 4 to 6 weeks.

Water samples were collected under baseflow and runoff conditions for determination of nutrient, herbicide, and sediment (runoff samples only) concentrations. Grab samples were collected at regular intervals under baseflow conditions, weekly from April through June and twice monthly from July through March. Storm runoff samples at Devils Icebox were collected with an Isco 2900 automatic sampler (Teledyne Isco, Inc. Lincoln, Nebraska) from April 1999 to July 2000 and a Sigma 900 automatic sampler (Hach Co., Loveland, Colorado) from August 2000 to March 2002. At Hunters Cave, a Sigma 900 automatic sampler was used throughout the study. All automatic samplers were equipped with $24,500 \mathrm{~mL}$ highdensity-polyethylene sample bottles. For the purpose of sample collection, a runoff event was defined as a 1.5 -fold increase in stage height. The stage height for triggering runoff sample collection was adjusted periodically based on ambient baseflow conditions. From April 1999 to July 2000, the automatic samplers were programmed to collect samples at 30-minute intervals throughout the course of an event, so sample collection occurred over a 12-hour period at both sites. By July 2000, a sufficient number of runoff events had been observed to assess the efficacy of the existing sampler programming. This evaluation showed that the existing programming was not sampling the later part of some runoff events at both sites. From August 2000 to March 2002, the samplers were re-programmed using variable time intervals, with decreasing sample frequency through the course of an event. Sampling intervals ranged from 5 minutes to 4 hours, with the programs designed to collect samples for an event length of $24 \mathrm{~h}$ at Hunters Cave and $36 \mathrm{~h}$ at Devils Icebox. The total number of samples collected at each site during the study for herbicide and nutrient analyses were 1031 at Hunters Cave and 765 at Devils Icebox. The higher number of samples at Hunters Cave resulted from the greater number of runoff events at this site over the course of the study.

Journal of Cave and Karst Studies, August 2011・103 
Additional monitoring was also performed to compare contaminant concentrations between the caves and their primary surface streams, Bonne Femme Creek for Devils Icebox and Bass Creek for Hunters Cave. Bonne Femme Creek was sampled at U.S. highway 63, upstream of the losing reach to Devils Icebox, and Bass Creek was sampled above the Hunters Cave spring resurgence. Grab samples were collected quarterly from the fourth quarter of 2003 through the third quarter of 2007 , for a total of 16 samples collected at each site.

\section{Analytical Procedures}

All samples were analyzed for nutrients and herbicides, and suspended-sediment analyses were also conducted for selected runoff events at both sites from 1999 to 2001. All samples were transported to the laboratory on ice and then refrigerated at 2 to $4{ }^{\circ} \mathrm{C}$ until filtered. Herbicide and dissolved-nutrient samples were filtered through $0.45 \mu \mathrm{m}$ nylon filters within 72 hours of collection.

Nutrient analyses included total and dissolved inorganic nitrogen and phosphorus species determined by standard colorimetric methods (Greenberg et al., 1992) using a Lachat flow injection system (Lachat Instruments, Loveland, Colorado). Total $\mathrm{N}$ and $\mathrm{P}$ were determined on thoroughly mixed, unfiltered $60 \mathrm{~mL}$ samples by autoclave digestion with potassium persulfate (Nydahl, 1978), which quantitatively converts all $\mathrm{N}$ forms to nitrate $\left(\mathrm{NO}_{3}^{-}\right)$and all $\mathrm{P}$ forms to orthophosphate $\left(\mathrm{PO}_{4}^{3-}\right)$ that were then determined colorimetrically. Nitrate+nitrite- $\mathrm{N}$ were determined by the cadmium reduction method (Greenberg et al., 1992). Since nitrite would not be expected to be significant in these samples, the nitrate+nitrite- $\mathrm{N}$ will be subsequently referred to as nitrate- $\mathrm{N}\left(\mathrm{NO}_{3}-\mathrm{N}\right)$. Ammonium- $\mathrm{N}\left(\mathrm{NH}_{4}-\mathrm{N}\right)$ was determined by the phenate method, and orthophosphate- $\mathrm{P}\left(\mathrm{PO}_{4}-\mathrm{P}\right)$ was determined by the ascorbic acid method (Greenberg et al., 1992). Method detection limits were $0.10 \mathrm{mg} \mathrm{L}^{-1}$ for total $\mathrm{N}$ and $\mathrm{NO}_{3}$ $\mathrm{N}, 0.020 \mathrm{mg} \mathrm{L}^{-1}$ for $\mathrm{NH}_{4}-\mathrm{N}$, and $0.005 \mathrm{mg} \mathrm{L}^{-1}$ for total $\mathrm{P}$ and $\mathrm{PO}_{4}-\mathrm{P}$. Organic $\mathrm{N}$ and $\mathrm{P}$ were computed as the difference between their respective total and inorganic concentrations.

Herbicide analyses were conducted for several of the commonly used soil-applied corn and soybean herbicides: atrazine [6-chloro- $N^{2}$-ethyl- $N^{4}$-(1-methylethyl)-1,3,5-triazine-2,4-diamine], alachlor [2-chloro- $N$-(2,6-diethylphenyl)- $N$-(methoxy-methyl)acetamide], acetochlor [2-chloro$N$-(ethoxymethyl)- $N$-(2-ethyl-6-methylphenyl)acetamide], metolachlor [2-chloro- $N$-(2-ethyl-6-methylphenyl)- $N$-(2methoxy-1-methylethyl)acetamide], and metribuzin [4amino-6-(1,1-dimethylethyl)-3-(methylthio)-1,2,4-triazin$5(4 H)$-one]. The stable atrazine metabolites deethylatrazine (DEA) [6-chloro- $N^{4}$-(1-methylethyl)-1,3,5-triazine2,4-diamine] and deisopropylatrazine (DIA) [6-chloro$N^{2}$-ethyl-1,3,5-triazine-2,4-diamine] were also analyzed. For all herbicides and metabolites, analyses were conducted by passing $200 \mathrm{~mL}$ samples, spiked with $100 \mathrm{ng}$ of terbutylazine, through $\mathrm{C}_{18}$ solid-phase extraction cartridges. The analytes were eluted in ethyl acetate and evaporated to about $0.3 \mathrm{~mL}$ under a stream of ultrapure $\mathrm{N}_{2}$ in a $30{ }^{\circ} \mathrm{C}$ water bath. Phenanthrene- $d 10$ was then added as an internal standard. The herbicides and metabolites were quantified by gas chromatography/mass spectrometry using a Varian 3400 gas chromatograph with a Saturn 2000 ion-trap mass-selective detector (Varian, Inc., Harbor City, California). Detection limits in $\mu \mathrm{g} \mathrm{L}^{-1}$ were atrazine, 0.003; alachlor, 0.003; acetochlor, 0.006; metolachlor, 0.002; metribuzin, 0.008; DEA, 0.004; and DIA, 0.008. Additional details of the herbicide analyses are in Lerch and Blanchard (2003).

Suspended-sediment analyses were performed by the evaporation method (Brakensiek et al., 1979) to develop a relationship between its concentration and turbidity. The method calls for adding a flocculant, but instead, samples were allowed to settle over a period of days to weeks, depending upon the clay content of the samples, before gravimetric analysis was performed. At Devils Icebox, 83 samples from eight runoff events in 1999 and 2000 were analyzed. At Hunters Cave, 300 samples from 19 runoff events in 1999 to 2001 were analyzed. Regression analysis was then used to correlate the suspended-sediment data to the turbidity data collected by the YSI Sonde. Given the absence of light in the cave streams, it was assumed that the algal contribution to the YSI turbidity data was negligible, so that the turbidity of the water was solely a function of suspended sediments. Turbidity data were selected for regression analysis using two methods, either choosing the data point closest in time to that of the runoff-sample collection or computing the average of the turbidity data that bracketed the runoff-sample collection time. At both sites, the turbidity data closest to the runoff-sample collection resulted in higher coefficients of determination $\left(r^{2}\right)$; and therefore, these regression equations were chosen to compute suspended sediment concentrations from the 15-minute turbidity data. The initial regression analyses for both sites resulted in non-significant and negative yintercepts, resulting in negative concentration estimates when turbidity values were low (e.g., $\leq 70$ NTU). To avoid this, the regression line was forced through zero, resulting in the following equations, where $S S$ is suspended sediments: for Devils Icebox, $S S=1.37 \times$ Turbidity $\left(r^{2}=\right.$ $0.71 ; p<0.001)$, and for Hunters Cave, $S S=1.30 \times$ Turbidity $\left(r^{2}=0.70 ; p<.001\right)$.

The constraint imposed when using regression through the origin requires an alternative to the ordinary least squares computation $r^{2}$. The computed values were determined using the approach described by Eisenhauer (2003). As can be seen from the resulting equations, there was a very significant correlation between turbidity and suspended sediments, and the slope of the regression lines was very similar between sites. This approach provided the equivalent of about 35,000 suspended sediment estimations per site per year. 


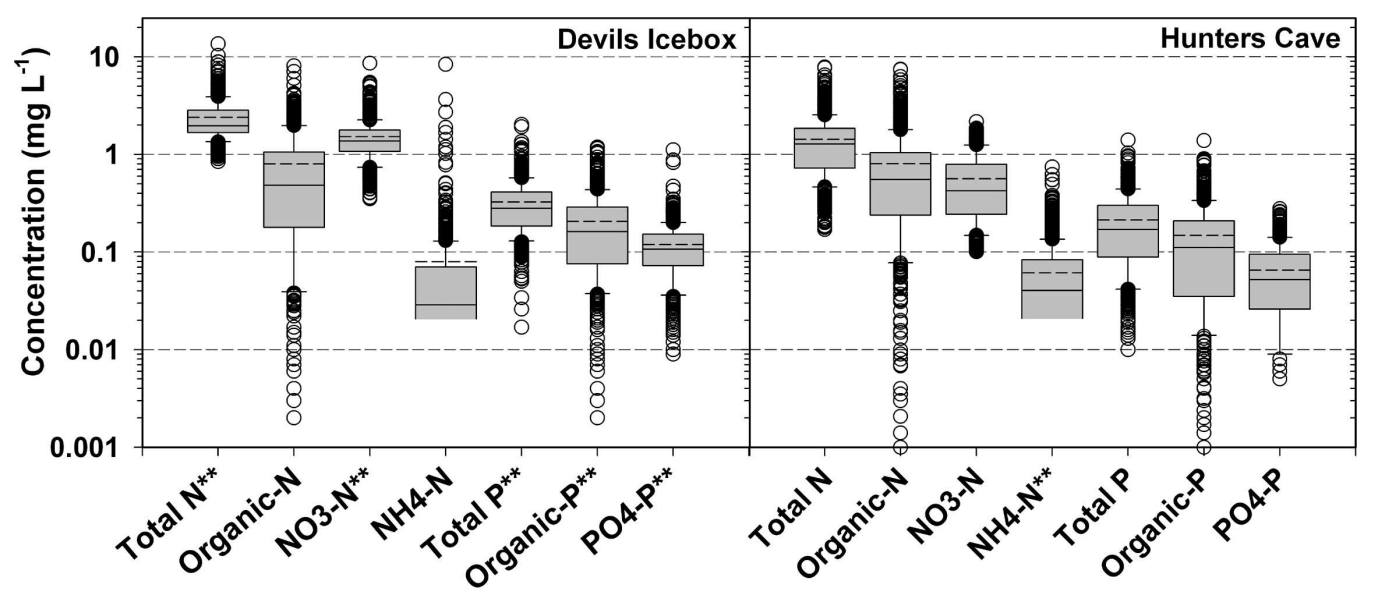

Figure 5. Box plot diagrams of nutrient concentrations in the Devils Icebox and Hunters Cave. The boxes show the $25^{\text {th }}$ to $75^{\text {th }}$ percentile concentrations with the median (solid line) and mean (dashed line) concentrations shown within the boxes. Whiskers represent the $10^{\text {th }}$ and $90^{\text {th }}$ percentiles and $\bigcirc$ represent outliers. $* *=$ significantly different at $p=0.01$ based on the Mann-Whitney U test.

\section{Load Computations and Statistical Analyses}

Contaminant loads were computed using concentration data from grab and automated samples and from the computed suspended-sediment concentrations combined with the 5-minute discharge data. Linear interpolation was used to estimate concentrations for any un-sampled period. The concentrations were then multiplied by the discharge to determine the load for each 5-minute interval. The 5minute load data were then aggregated to a daily, quarterly, or annual basis as needed. The data were expressed as contaminant flux (e.g., $\mathrm{g} \mathrm{km}^{-2} \mathrm{~d}^{-1}$ ) for the daily data, percent of the annual load for the quarterly data, and areal loss rates (e.g., $\mathrm{kg} \mathrm{ha}^{-1} \mathrm{y}^{-1}$ ) for the annual data. Nutrient and sediment areal-loss rates were based on the entire recharge area, and herbicide loss rates were expressed on a treated-area basis. Since the concentration and areal-loss data were not normally distributed based on the Kolmogorov-Smirnov test, statistical differences between sites were determined using the Mann-Whitney Utest. The U-test is a non-parametric test of the differences in mean rank between two data sets. For comparisons of concentration data between sites, the a priori level of significance was chosen to be $\alpha=0.05$ because of the large number of observations for each contaminant $(n>700)$. This was also the significance level used for U-tests to determine differences in contaminant concentrations between the caves and their primary surface streams $(n=16)$. For the areal-loss data, the a priori level of significance was chosen to be $\alpha=0.10$, because comparisons between sites were only performed on the annual data $(n=3)$.

\section{Results AND Discussion}

\section{HYDROLOGY}

The area-normalized discharge from the Devils Icebox resurgence $\left(43,500\right.$ to $\left.74,700 \mathrm{~m}^{3} \mathrm{~km}^{-2}\right)$ was consistently greater than the Hunters Cave resurgence (19,600 to $43,300 \mathrm{~m}^{3} \mathrm{~km}^{-2}$ ) during three years of monitoring (Lerch et al., 2005). In addition, the Devils Icebox recharge area was seen to have much greater peak discharge during runoff events, greater water-storage capacity, and longer flow paths than the Hunters Cave recharge area. Hunters Cave had more frequent runoff events, greater median instantaneous discharge, and more pronounced seasonal changes in discharge, water temperature, and dissolved oxygen than Devils Icebox. The Hunters Cave discharge characteristics suggest that the areal extent and size of subsurface conduits are very limited in this recharge area. In contrast, the Devils Icebox resurgence is characterized by a sub-surface conduit system that is both greater in volume and areal extent than Hunters Cave (Lerch et al., 2005).

\section{Nutrient Concentrations}

Nitrogen concentration data showed that Devils Icebox had significantly greater concentrations than Hunters Cave for total $\mathrm{N}$ and $\mathrm{NO}_{3}-\mathrm{N}$ (Fig. 5). Total $\mathrm{N}$ concentrations showed a similar range between sites, but Devils Icebox had $68 \%$ greater mean and $54 \%$ greater median concentrations than Hunters Cave. At both sites, total $\mathrm{N}$ concentrations showed a very narrow range between the $10^{\text {th }}$ and $90^{\text {th }}$ percentiles $\left(2.07 \mathrm{mg} \mathrm{L}^{-1}\right.$ at Hunters Cave and $2.52 \mathrm{mg} \mathrm{L}^{-1}$ at Devils Icebox), indicating consistently high total $\mathrm{N}$ contamination over time. This was especially the case at Devils Icebox, where only eight samples out of 765 (i.e., $1.1 \%$ ) were below $1 \mathrm{mg} \mathrm{L}^{-1}$, but $37 \%$ of the samples collected at Hunters Cave were below $1 \mathrm{mg} \mathrm{L}^{-1}$. Among the nutrient analytes measured or computed, $\mathrm{NO}_{3}-\mathrm{N}$ showed the highest relative difference between sites, with mean concentrations that were 2.7 times greater at Devils Icebox $\left(1.52 \mathrm{mg} \mathrm{L}^{-1}\right)$ than Hunters Cave $\left(0.57 \mathrm{mg} \mathrm{L}^{-1}\right)$. Similar to total $\mathrm{N}$, the distribution of $\mathrm{NO}_{3}-\mathrm{N}$ concentrations also showed a narrow range between $10^{\text {th }}$ and $90^{\text {th }}$ 
Table 1. Comparison of mean nitrogen and phosphorus concentrations between the caves and their primary surface streams based on quarterly samples collected from 2003 to $2007(n=16)$. Bold type indicates a significant difference between mean ranks for the Mann-Whitney U-test $(\alpha=\mathbf{0 . 0 5})$. The p-values represent the probability of observing a more extreme value for the U statistic.

\begin{tabular}{lcccccc}
\hline Nutrient & $\begin{array}{c}\text { Devils Icebox, } \\
\mathrm{mg} \mathrm{L}^{-1}\end{array}$ & $\begin{array}{c}\text { Bonne Femme } \\
\text { Cr., } \mathrm{mg} \mathrm{L}^{-1}\end{array}$ & $p$-value & $\begin{array}{c}\text { Hunters Cave, } \\
\mathrm{mg} \mathrm{L}^{-1}\end{array}$ & $\begin{array}{c}\text { Bass Cr., } \\
\mathrm{mg} \mathrm{L}^{-1}\end{array}$ & $p$-value \\
\hline Total $\mathrm{N}$ & $\mathbf{2 . 0 2}$ & $\mathbf{1 . 2 6}$ & $\mathbf{0 . 0 1 7}$ & $\mathbf{0 . 6 5}$ & $\mathbf{1 . 3 7}$ & $\mathbf{0 . 0 0 5}$ \\
$\mathrm{NO}_{3}$-N & $\mathbf{1 . 6 2}$ & $\mathbf{0 . 9 7}$ & $\mathbf{0 . 0 0 4}$ & $\mathbf{0 . 2 6}$ & $\mathbf{0 . 8 7}$ & $\mathbf{0 . 0 0 9}$ \\
$\mathrm{NH}_{4}-\mathrm{N}$ & 0.03 & 0.07 & 0.080 & 0.02 & 0.03 & 0.087 \\
Total $\mathrm{P}$ & 0.19 & 0.30 & 0.152 & 0.10 & 0.10 & 0.494 \\
$\mathrm{PO}_{4}-\mathrm{P}$ & $\mathbf{0 . 1 3}$ & $\mathbf{0 . 1 8}$ & $\mathbf{0 . 0 0 7}$ & 0.05 & 0.05 & 0.152 \\
\hline
\end{tabular}

percentiles at both sites, but concentrations at Devils Icebox were greater throughout the distribution. Organic$\mathrm{N}$ concentrations showed nearly equal distributions, and the mean concentration at both sites was $0.80 \mathrm{mg} \mathrm{L}^{-1}$. Despite significantly lower total $\mathrm{N}$ and $\mathrm{NO}_{3}-\mathrm{N}$ concentrations at Hunters Cave, the relative difference between the total $\mathrm{N}$ and inorganic $\mathrm{N}$ analytes was nearly identical between sites. Although $\mathrm{NH}_{4}-\mathrm{N}$ at both sites had the lowest overall concentrations of any nutrient species monitored, Hunters Cave had significantly greater $\mathrm{NH}_{4}-$ $\mathrm{N}$ concentrations than Devils Icebox. Median $\mathrm{NH}_{4}-\mathrm{N}$ concentrations were $0.04 \mathrm{mg} \mathrm{L}^{-1}$ at Hunters Cave and $0.03 \mathrm{mg} \mathrm{L}^{-1}$ at Devils Icebox. The consistently low $\mathrm{NH}_{4}-\mathrm{N}$ concentrations were not expected, given the near certainty of ammonia-based fertilizer inputs from row-crop areas and the high fecal coliform levels observed at both sites (Lerch et al., 2002), indicating significant wastewater inputs. However, dissolved $\mathrm{O}_{2}$ concentrations at both sites were generally at or slightly above saturation throughout this study (Lerch et al., 2005), and the $\mathrm{NH}_{4}^{+}$was apparently being oxidized to $\mathrm{NO}_{3}^{-}$during transport.

Concentrations of the three $\mathrm{P}$ analytes were significantly greater at Devils Icebox than Hunters Cave (Fig. 5). The range in $10^{\text {th }}$ to $90^{\text {th }}$ percentile concentrations was similar between sites, indicating similar variation in $\mathrm{P}$ inputs, but Devils Icebox was consistently greater in both mean and median P concentrations. For example, average Devils Icebox concentrations were 1.5 times greater for total $\mathrm{P}, 1.4$ times greater for organic- $\mathrm{P}$, and 1.8 times greater for $\mathrm{PO}_{4}-\mathrm{P}$ than Hunters Cave. Only $\mathrm{NO}_{3}-\mathrm{N}$ had a greater relative difference between sites than $\mathrm{PO}_{4}-\mathrm{P}$. Since $\mathrm{PO}_{4}-\mathrm{P}$ is quite insoluble at the $\mathrm{pH}$ of 7.5 to 7.8 observed under typical baseflow conditions for the cave streams (Lerch et al., 2005), it was expected that $\mathrm{PO}_{4}-\mathrm{P}$ concentrations at Devils Icebox would be lower than Hunters Cave, given the greater possibility for $\mathrm{PO}_{4}^{3-}$ precipitation to occur along its much longer flow path (Lerch et al., 2005). Despite this, all $\mathrm{P}$ analytes were greater at Devils Icebox, demonstrating that the Devils Icebox recharge area was either more vulnerable to $\mathrm{P}$ transport or had much greater $\mathrm{P}$ inputs to its recharge area (see below).
Quarterly samples were collected from the caves and their primary surface streams to assess any differences in $\mathrm{N}$ and $\mathrm{P}$ concentrations that may occur along the subsurface flow paths. These data showed that for Devils Icebox total $\mathrm{N}$ and $\mathrm{NO}_{3}-\mathrm{N}$ significantly increased, and $\mathrm{NH}_{4}-\mathrm{N}$ slightly decreased compared to Bonne Femme Creek (Table 1). Apparently the Pierpont sinkhole plain, which lies between the losing reach of Bonne Femme Creek and the cave stream resurgence, is the source of the additional $\mathrm{N}$ to the Devils Icebox cave stream. The decrease in average $\mathrm{NH}_{4}-\mathrm{N}$ concentrations from $0.07 \mathrm{mg} \mathrm{L}^{-1}$ in Bonne Femme Creek to $0.03 \mathrm{mg} \mathrm{L}^{-1}$ in Devils Icebox suggests that some minor losses occurred along the subsurface flow path, but the input concentrations were already very low before recharge to the Devils Icebox aquifer had occurred. At Hunters Cave, all $\mathrm{N}$ analytes were lower than Bass Creek, and total $\mathrm{N}$ and $\mathrm{NO}_{3}-\mathrm{N}$ concentrations were significantly lower. For the $\mathrm{P}$ analytes, total $\mathrm{P}$ and $\mathrm{PO}_{4}-\mathrm{P}$ were lower in Devils Icebox than Bonne Femme Creek, indicating that some $\mathrm{PO}_{4}^{3-}$ precipitation occurred in the subsurface, and the differences were statistically significant for $\mathrm{PO}_{4}-\mathrm{P}$. Comparison of Hunters Cave to Bass Creek showed that the two sites had equal average total $\mathrm{P}$ and $\mathrm{PO}_{4}-\mathrm{P}$ concentrations. The finding that total $\mathrm{N}$ and $\mathrm{NO}_{3}-\mathrm{N}$ significantly decreased while total $\mathrm{P}$ and $\mathrm{PO}_{4}-\mathrm{P}$ were unchanged between Hunters Cave and Bass Creek suggests that the Turkey Creek tributaries had much lower $\mathrm{N}$ concentrations but similar P concentrations to that of Bass Creek.

The concentrations of $\mathrm{N}$ and $\mathrm{P}$ species observed in this study were generally within the lower range reported for karst aquifers (Boyer and Pasquarell, 1996; Johnson, 2002; Katz, 2004; Panno and Kelly, 2004). In The Hole cave in West Virginia, Boyer and Pasquarell (1996) reported median $\mathrm{NO}_{3}-\mathrm{N}$ concentrations in the main cave stream and its tributaries ranging from 3.40 to $16.58 \mathrm{mg} \mathrm{L}^{-1}$. Tributaries impacted by a dairy operation had much greater $\mathrm{NO}_{3}-\mathrm{N}$ concentrations than those in tributaries draining pasture land (Boyer and Pasquarell, 1996), which were similar to the $\mathrm{NO}_{3}-\mathrm{N}$ concentrations observed in Devils Icebox and Hunters Cave. Katz (2004) reported that $\mathrm{NO}_{3}-\mathrm{N}$ concentrations in northern Florida springs ranged 
Table 2. Herbicide detections and concentrations for Hunters Cave and Devils Icebox recharge areas.

\begin{tabular}{|c|c|c|c|c|c|c|}
\hline \multirow[b]{2}{*}{ Herbicide } & \multicolumn{3}{|c|}{ Devils Icebox } & \multicolumn{3}{|c|}{ Hunters Cave } \\
\hline & $\begin{array}{c}\text { Detection } \\
\text { Frequency, \% }\end{array}$ & $\begin{array}{l}\text { Concentration } \\
\text { Range, } \mu \mathrm{g} \mathrm{L}^{-1}\end{array}$ & $\begin{array}{l}\text { Median, } \\
\mu \mathrm{g} \mathrm{L}^{-1}\end{array}$ & $\begin{array}{c}\text { Detection } \\
\text { Frequency, \% }\end{array}$ & $\begin{array}{l}\text { Concentration } \\
\text { Range, } \mu \mathrm{g} \mathrm{L}^{-1}\end{array}$ & $\begin{array}{l}\text { Median, } \\
\mu \mathrm{g} \mathrm{L}^{-1}\end{array}$ \\
\hline Atrazine & 94.9 & $<0.003-36.9$ & 0.058 & 77.4 & $<0.003-75.6$ & 0.036 \\
\hline DIA & 36.3 & $<0.008-4.42$ & $<0.008$ & 41.0 & $<0.008-0.703$ & $<0.008$ \\
\hline DEA & 88.2 & $<0.004-6.18$ & 0.086 & 67.8 & $<0.004-1.02$ & 0.028 \\
\hline Metribuzin & 37.6 & $<0.008-0.280$ & $<0.008$ & 40.3 & $<0.008-0.356$ & $<0.008$ \\
\hline Acetochlor & 18.7 & $<0.006-5.82$ & $<0.006$ & 9.0 & $<0.006-2.58$ & $<0.006$ \\
\hline Alachlor & 45.2 & $<0.003-0.400$ & $<0.003$ & 48.4 & $<0.003-5.17$ & $<0.003$ \\
\hline Metolachlor & 57.0 & $<0.002-4.06$ & 0.005 & 24.1 & $<0.002-0.206$ & $<0.002$ \\
\hline
\end{tabular}

from 0.50 to $4.2 \mathrm{mg} \mathrm{L}^{-1}$, levels that were very similar to those observed in this study. Samples collected from 35 springs discharging from carbonate bedrock in the Upper Tennessee Valley and Ridge physiographic province gave median concentrations of $\mathrm{N}$ and $\mathrm{P}$ species considerably lower than those reported here (Johnson, 2002). Currens (2002) reported average annual concentrations of $\mathrm{NO}_{3}-\mathrm{N}$ and $\mathrm{PO}_{4}-\mathrm{P}$ in the intensively row-cropped Pleasant Grove Spring recharge area in Kentucky. The average $\mathrm{NO}_{3}-\mathrm{N}$ concentrations ranged from 4.20 to $4.98 \mathrm{mg} \mathrm{L}^{-1}$ over a 7year period, levels that were about 8 and 3 times greater than the average $\mathrm{NO}_{3}-\mathrm{N}$ concentrations in Devils Icebox and Hunters Cave, respectively. In the same study, median $\mathrm{PO}_{4}-\mathrm{P}$ concentrations in the first four years were similar to or lower than those reported here, but in the last two years increased to concentrations that were 2 to 5 times greater than those in Hunters Cave or Devils Icebox.

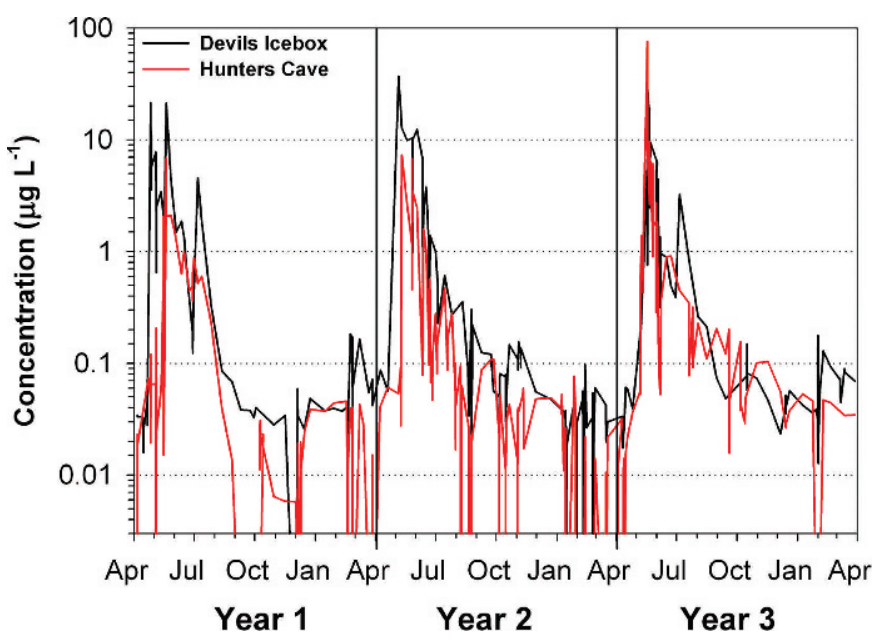

Figure 6. Atrazine concentrations in the Devils Icebox and Hunters Cave from April 1999 through March 2002. Graph represents all samples collected over the study $(n=765$ for Devils Icebox; $\mathbf{n}=1031$ for Hunters Cave).

\section{Herbicide Concentrations}

Herbicides were frequently detected at both sites (Table 2). Overall, $96 \%$ of Devils Icebox samples and $85 \%$ of Hunters Cave samples had a detection of at least one herbicide or metabolite compound. At both sites, atrazine and its DEA metabolite were most commonly detected, but the frequency was much greater for both compounds at Devils Icebox. The DIA metabolite was detected much less often than atrazine and DEA at both sites. The frequency of alachlor and metribuzin detections was similar between sites, but acetochlor and metolachlor were more often detected at Devils Icebox. Despite the frequent detections, herbicide concentrations were quite low overall, with median concentrations generally below the detection limits and none greater than $0.100 \mu \mathrm{g} \mathrm{L}^{-1}$. As illustrated by the changes in atrazine at both sites (Fig. 6), herbicide concentrations showed a typical seasonal trend, with the greatest concentrations occurring in spring, followed by an exponential decrease to very low levels (e.g., $<0.100 \mu \mathrm{g} \mathrm{L}^{-1}$ ) by late summer. In general, herbicide detection frequency and median concentrations of these two karst aquifers were considerably less than those in surface streams of this region (Lerch and Blanchard, 2003). However, they were similar to the levels of herbicides reported in other karst aquifers (Pasquarell and Boyer, 1996; Currens, 2002; Panno and Kelly, 2004). Peak concentrations of atrazine and metolachlor in Devils Icebox and Hunters Cave were very similar to those reported for karst aquifers in Kentucky (Currens, 2002) and Illinois (Taylor et al., 2000; Panno and Kelly, 2004) in which the relative proportion of crop land within these recharge areas was similar to or greater than that of Devils Icebox and Hunters Cave.

\section{CONTAMINANT LOADS}

Based on the large annual mass transport of suspended sediment $(>100,000 \mathrm{~kg})$ and nutrients $(>100 \mathrm{~kg} \mathrm{P}$ and $>1000 \mathrm{~kg} \mathrm{~N}$ ) at each site, it is believed that the monitored contaminants were derived primarily from allochthonous sources distributed throughout the recharge areas. The 
Table 3. Annual nutrient loads for Devils Icebox and Hunters Cave recharge areas.

\begin{tabular}{|c|c|c|c|c|c|c|c|c|}
\hline \multirow[b]{2}{*}{ Contaminant } & \multicolumn{4}{|c|}{ Devils Icebox, kg } & \multicolumn{4}{|c|}{ Hunters Cave, kg } \\
\hline & Year 1 & Year 2 & Year 3 & Mean & Year 1 & Year 2 & Year 3 & Mean \\
\hline Suspended Sediment & 449,000 & 881,000 & 387,000 & 572,000 & 69,000 & 154,000 & 113,000 & 112,000 \\
\hline Total N & 3,740 & 6,110 & 3,330 & 4,390 & 730 & 1,760 & 1,100 & 1,197 \\
\hline Organic-N & 1,700 & 2,050 & 636 & 1,460 & 415 & 1,100 & 494 & 670 \\
\hline $\mathrm{NO}_{3}-\mathrm{N}$ & 1,960 & 3,940 & 2,520 & 2,810 & 288 & 600 & 524 & 471 \\
\hline $\mathrm{NH}_{4}-\mathrm{N}$ & 79.0 & 121 & 178 & 126 & 26.5 & 62.6 & 81.6 & 56.9 \\
\hline Total P & 518 & 969 & 391 & 626 & 98 & 240 & 188 & 175 \\
\hline Organic-P & 348 & 652 & 170 & 390 & 64 & 174 & 96 & 111 \\
\hline $\mathrm{PO}_{4}-\mathrm{P}$ & 170 & 317 & 221 & 236 & 34 & 67 & 92 & 64 \\
\hline
\end{tabular}

herbicide transport data (Tables 3 and 4) further support this assumption, as the use of herbicides would have been restricted to farm fields within the recharge areas, and the seasonal nature of the herbicide concentrations indicated that new inputs occurred annually. Although autochthonous sediments could be potential sources of contaminants, the mass transported annually suggests that they were trivial compared to allochthonous sources. For example, the average annual mass of sediment transported was $112,000 \mathrm{~kg}$ at Hunters Cave and 572,000 $\mathrm{kg}$ at Devils Icebox (Tables 3 and 4). Sources of such large amounts of suspended sediment, if primarily derived from re-suspension of autochthonous bed and bank sediments, would be readily observed along the stream channels within the caves. However, personal observation of these caves over time has shown minor erosion of bed and bank sediments, but sediment deposition was frequently observed in the stream channels following large runoff events.

The quarterly distribution of contaminant loads and stream discharge for Devils Icebox and Hunters Cave, averaged over all three years, is shown in Figure 7. For Devils Icebox, total $\mathrm{N}$ and $\mathrm{P}$ loads by quarter of the year were nearly identical and strongly tied to seasonal discharge. In the second quarter, $45 \%$ of the year's discharge occurred along with $49 \%$ of the total $\mathrm{N}$ load and $48 \%$ of the total P load. For suspended sediment, 50\% of the annual load occurred in the second quarter, but it differed from the total $\mathrm{N}$, total $\mathrm{P}$, and discharge distributions in the other quarters. For example, $21 \%$ of the annual sediment load was transported in the third quarter while only $12 \%$ of the discharge, $10 \%$ of the total $\mathrm{N}$, and $13 \%$ of the total $\mathrm{P}$ transport occurred during this quarter. For Hunters Cave, nutrient and sediment loads were more evenly distributed over the year, and loads were not as strongly associated with discharge in the first, third, and fourth quarters as was observed at Devils Icebox (Fig. 7). Similar to Devils Icebox, second quarter discharge and loads of sediment, total $\mathrm{N}$, and total $\mathrm{P}$ accounted for the highest proportion of the year's load, with $34 \%$ of the annual discharge, $37 \%$ of the sediment load, $41 \%$ of the total $\mathrm{N}$ load, and $31 \%$ of the total $\mathrm{P}$ load. However, the third and fourth quarter loads of sediments and nutrients were proportionally much greater at Hunters Cave compared to Devils Icebox. Hunters Cave discharge was most disproportionate to sediment and nutrient loads in the first quarter, when $27 \%$ of the annual discharge occurred, compared to $16 \%$ of the sediment load, $22 \%$ of the total $\mathrm{N}$ load, and $20 \%$ of the total $\mathrm{P}$ load. The high relative sediment transport in the third quarter of the year at both sites was largely attributed to a single runoff event

Table 4. Annual herbicide loads for Devils Icebox and Hunters Cave recharge areas.

\begin{tabular}{|c|c|c|c|c|c|c|c|c|}
\hline \multirow[b]{2}{*}{ Contaminant } & \multicolumn{4}{|c|}{ Devils Icebox, $\mathrm{g}$} & \multicolumn{4}{|c|}{ Hunters Cave, g } \\
\hline & Year 1 & Year 2 & Year 3 & Mean & Year 1 & Year 2 & Year 3 & Mean \\
\hline Atrazine & 3,950 & 3,010 & 2.230 & 3,060 & 287 & 463 & 1,730 & 827 \\
\hline $\mathrm{DEA}^{\mathrm{a}}$ & 807 & 1,180 & 663 & 883 & 47.2 & 174 & 180 & 134 \\
\hline $\mathrm{DIA}^{\mathrm{b}}$ & 291 & 1,180 & 330 & 600 & 23.2 & 89.8 & 108 & 73.7 \\
\hline Metribuzin & 105 & 37.5 & 15.3 & 52.4 & 34.9 & 22.5 & 2.68 & 20.0 \\
\hline Acetochlor & 402 & 40.1 & 2.34 & 148 & 2.10 & 2.13 & 6.44 & 3.56 \\
\hline Alachlor & 49.7 & 28.1 & 18.0 & 31.9 & 28.8 & 50.6 & 25.3 & 34.9 \\
\hline Metolachlor & 165 & 113 & 352 & 210 & 1.88 & 1.43 & 6.59 & 3.30 \\
\hline
\end{tabular}

${ }^{\mathrm{a}}$ DEA $=$ Deethylatrazine.

${ }^{\mathrm{b}}$ DIA $=$ Deisopropylatrazine

Note: Both metabolite loads are expressed on an atrazine basis by correcting for the difference in molecular weight of the metabolites relative to that of atrazine. 


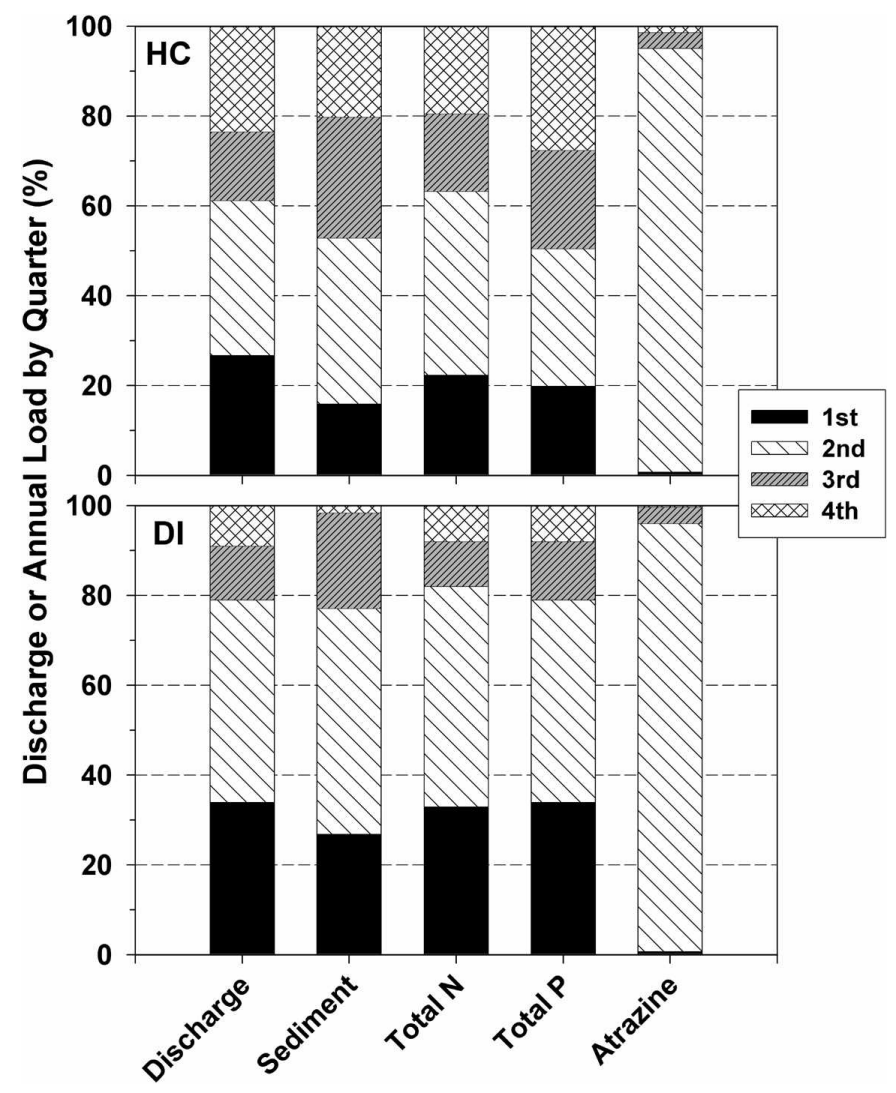

Figure 7. Quarterly distribution of discharge, suspended sediment, total $\mathrm{N}$, total $\mathrm{P}$, and atrazine loads for Devils Icebox and Hunters Cave.

that occurred in August 2000. This event had the highest discharge and sediment transport of any event in the threeyear monitoring period. The strong relationship between seasonal discharge and total $\mathrm{N}$ and $\mathrm{P}$ transport at Devils Icebox indicated that nutrient transport was significant even under baseflow conditions, while at Hunters Cave the majority of the nutrient transport occurred during runoff events. This is not to say that sediment-bound $\mathrm{N}$ and $\mathrm{P}$ transport at Devils Icebox was unimportant; the highest concentrations and daily loads of both nutrients always occurred during runoff events (see below).

The seasonal distribution of atrazine loads was very similar at both sites, but it showed a very different pattern than discharge and nutrients. In the second quarter, atrazine loads accounted for $95 \%$ of the annual load at Devils Icebox and $94 \%$ of the annual load at Hunters Cave, demonstrating the extreme seasonality typical of herbicide transport (Thurman et al., 1991; Lerch et al., 1995). The seasonal atrazine transport pattern was also representative of the other herbicides monitored. The seasonal dependence of atrazine transport occurs because farmers apply herbicides during a relatively narrow window in April and May and they have relatively short persistence in the environment.

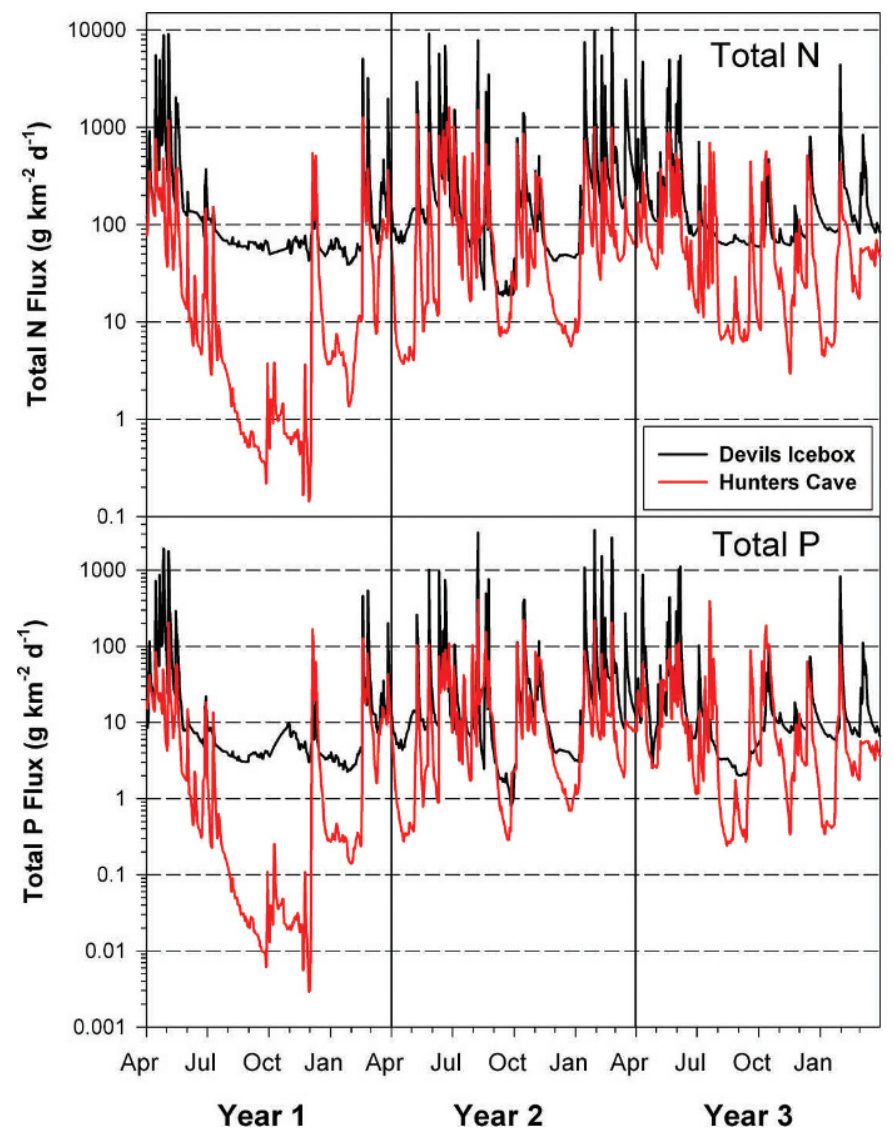

Figure 8. Estimated daily flux from each square kilometer of source area of total $\mathbf{N}$ and total $\mathbf{P}$ in Devils Icebox and Hunters Cave.

\section{Nutrient FLUX}

With the intensive monitoring approach used in this study, the flux of contaminants could be determined on a daily basis, providing highly time-resolved estimates of contaminant inputs to the two recharge areas. Of particular importance to the stygobites is the flux of nutrients occurring in the cave streams. High nutrient fluxes have been associated with the loss of stygobite diversity and changes in the distribution and abundance of species within caves (Elliott, 2000). Total fluxes of all types of $\mathrm{N}$ and $\mathrm{P}$ from each square kilometer of recharge area are shown as examples of the daily flux data (Fig. 8) that can be generated for any of the contaminants monitored in this study. Total $\mathrm{N}$ in Devils Icebox ranged from 19 to $11,000 \mathrm{~g} \mathrm{~km}^{-2} \mathrm{~d}^{-1}$, with a median flux of $96 \mathrm{~g} \mathrm{~km}^{-2} \mathrm{~d}^{-1}$. At Hunters Cave, total $\mathrm{N}$ ranged from 0.14 to $1600 \mathrm{~g} \mathrm{~km}^{-2} \mathrm{~d}^{-1}$, with a median flux of $30 \mathrm{~g} \mathrm{~km}^{-2} \mathrm{~d}^{-1}$. For total P, Devils Icebox ranged from 0.81 to $3400 \mathrm{~g} \mathrm{~km}^{-2} \mathrm{~d}^{-1}$, and Hunters Cave ranged from 0.003 to $410 \mathrm{~g} \mathrm{~km}^{-2} \mathrm{~d}^{-1}$. Median P flux was $8.5 \mathrm{~g} \mathrm{~km}^{-2} \mathrm{~d}^{-1}$ in Devils Icebox and $3.3 \mathrm{~g} \mathrm{~km}^{-2} \mathrm{~d}^{-1}$ in Hunters Cave. Thus, the median fluxes of total $\mathrm{N}$ and total $\mathrm{P}$ were about three times greater in Devils Icebox than Hunters Cave. The $\mathrm{N}$ 
and $\mathrm{P}$ fluxes were dominated by runoff events, resulting in sharp increases of several orders of magnitude in the daily fluxes for days in which runoff events occurred, regardless of the time of year (Fig. 8). If the inputs of $\mathrm{N}$ and $\mathrm{P}$ were primarily derived from fertilizer sources, these would have been greatest in spring, following fertilizer application to crop and pasture fields. However, the peak spring fluxes were very similar to those observed in other seasons. For instance, in Year 2, similarly high $\mathrm{N}$ and $\mathrm{P}$ fluxes were observed in spring, summer, and winter at both sites (Fig. 8). Thus, runoff events with enough energy to cause significant erosion were transporting large quantities of sorbed $\mathrm{N}$ and $\mathrm{P}$, in addition to soluble forms of the nutrients.

There have been only a few studies that have reported nutrient fluxes or loads for karst aquifers (Boyer and Pasquarell, 1996; Currens, 2002; Panno and Kelly, 2004; Katz et al., 2009). Of these studies, only two, Boyer and Pasquarell (1996) and Panno and Kelly (2004), were conducted in recharge areas with agricultural land use intensity comparable to the Devils Icebox and Hunters Cave recharge areas. Boyer and Pasquarell (1996) reported $\mathrm{NO}_{3}-\mathrm{N}$ loads for the basin drained by The Hole in West Virginia on three separate days. These loads were divided by the known area of the basin $\left(14.5 \mathrm{~km}^{2}\right)$ (Boyer, 2005) for the sake of comparability, resulting in $\mathrm{NO}_{3}-\mathrm{N}$ fluxes that ranged from 250 to $3500 \mathrm{~g} \mathrm{~km}^{-2} \mathrm{~d}^{-1}$. Panno and Kelly (2004) reported average $\mathrm{NO}_{3}-\mathrm{N}$ fluxes of approximately $5600 \mathrm{~g} \mathrm{~km}^{-2} \mathrm{~d}^{-1}$ for a southwest Illinois recharge area. The study by Currens (2002) was conducted in an intensively (69 to $78 \%$ ) row-cropped recharge area, resulting in average $\mathrm{NO}_{3}-\mathrm{N}$ fluxes ranging from 3400 to $13,000 \mathrm{~g} \mathrm{~km}^{-2} \mathrm{~d}^{-1}$. The data presented for Devils Icebox and Hunters Cave are total $\mathrm{N}$ fluxes, of which the $\mathrm{NO}_{3}-\mathrm{N}$ was a subset, indicating that reported $\mathrm{N}$ loads and fluxes in other karst aquifers with significant agricultural land uses were much greater than those for Devils Icebox and Hunters Cave. Using data from Currens (2002), estimated average $\mathrm{PO}_{4}-\mathrm{P}$ fluxes in the Pleasant Grove Spring recharge area ranged from 31 to $727 \mathrm{~g} \mathrm{~km}^{-2} \mathrm{~d}^{-1}$, fluxes that were 4 to 220 times greater than the total P fluxes in Devils Icebox and Hunters Cave.

\section{Areal Loss Rates}

To facilitate comparisons between sites, annual contaminant loads were computed on an areal loss basis (Fig. 9). With the exception of $\mathrm{NH}_{4}-\mathrm{N}$ loss rates, $\mathrm{N}, \mathrm{P}$, and sediment losses were significantly greater at Devils Icebox compared to Hunters Cave. Areal loss rates of $\mathrm{NO}_{3}-\mathrm{N}$ and suspended sediment at Devils Icebox were more than 5 times greater than at Hunters Cave. Total $\mathrm{N}$ and $\mathrm{P}$ and $\mathrm{PO}_{4}-\mathrm{P}$ loss rates were all more than 3 times greater at Devils Icebox than at Hunters Cave. The herbicide transport data showed that only metolachlor loss rates were significantly greater at Devils Icebox compared to Hunters Cave (Fig. 9), but atrazine and acetochlor losses

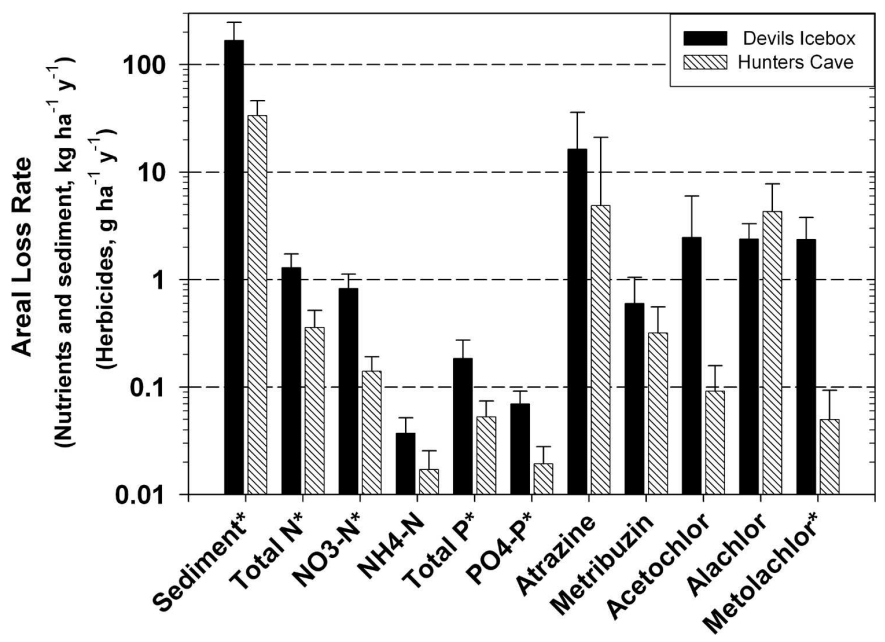

Figure 9. Average annual areal loss rates of suspended sediment, nutrients, and herbicides for Devils Icebox and Hunters Cave. Entire source area used for the first six columns; only treated row-crop area used for the last five. Note that areal loss rates for atrazine include the contribution of deethylatrazine and deisopropylatrazine. Error bars indicate one standard deviation. ${ }^{*}=$ significantly different at $\mathbf{p}=\mathbf{0 . 0 5}$ based on the Mann-Whitney $U$ test.

were also much greater at Devils Icebox, while alachlor losses were greater at Hunters Cave. The large variation in atrazine and acetochlor losses precluded statistically significant differences from being discerned. Metribuzin loss rates were similar between sites.

Herbicide and suspended sediment loss rates from the Devils Icebox and Hunters Cave recharge areas were generally much lower than those measured for other surface watersheds of the Midwestern US (Saxton et al., 1971; Larson et al., 1983; Lerch and Blanchard, 2003). Suspended sediment transport was one to two orders of magnitude below that typically measured for agricultural watersheds (Saxton et al., 1971; Larson et al., 1983). In karst aquifers, suspended sediment loss rates reported by Currens (2002) ranged from 530 to $1500 \mathrm{~kg} \mathrm{ha}^{-1}$, rates that were 3 to 43 times greater than those reported here and were similar to surface watersheds. Panno and Kelly (2004) and Currens (2002) reported $\mathrm{NO}_{3}-\mathrm{N}$ areal loss rates that were 20 to 190 times greater than those reported for Devils Icebox and Hunters Cave. However, areal loss rates of atrazine, metolachlor, and alachlor in these same two studies (Panno and Kelly, 2004; Currens, 2002) were very similar to those observed for Devils Icebox and Hunters Cave. It should be noted, though, that the loss rates reported here were on a treated-area basis, while those reported by Panno and Kelly (2004) were based on the total row-crop area, and those reported by Currens (2002) were reported for the entire recharge area. Thus, the herbicide loss rates for Devils Icebox and Hunters Cave 


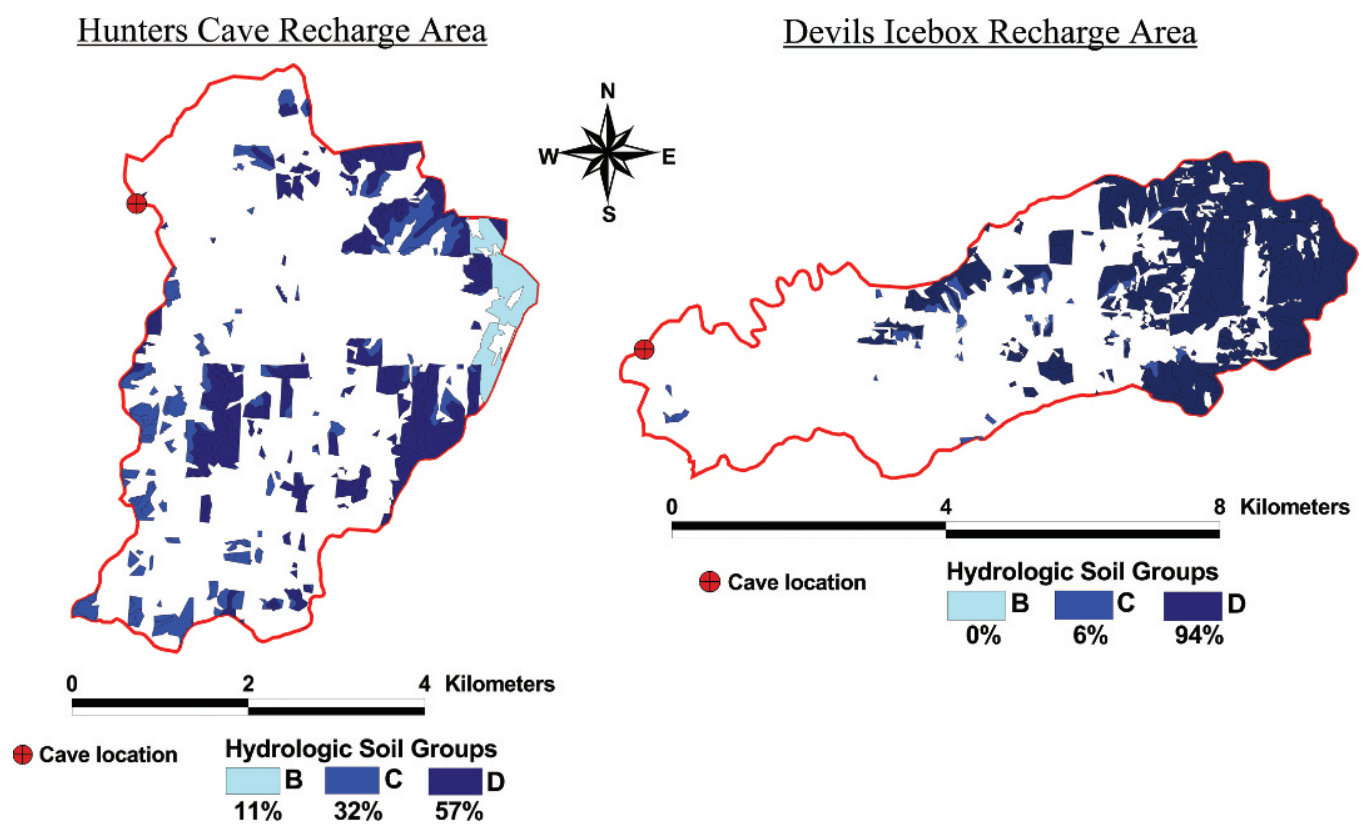

Figure 10. Hydrologic soil groups in the row-crop areas in each recharge area. Numbers below the color keys represents the proportion of row crops occurring on each soil type.

were most likely lower than those reported by Panno and Kelly (2004) and Currens (2002).

The higher areal loss rates of Devils Icebox compared to Hunters Cave were related to its consistently greater discharge and contaminant concentrations. While greater discharge is a function of the recharge area characteristics (Lerch et al., 2005), the greater observed concentrations at Devils Icebox were related to the occurrence of row crops on soils with high runoff potential. Hydrologic Soil Groups (HSG) represent one way to characterize the runoff potential of soils (USDA-NRCS, 2009). There are four categories of HSG, A through D, with HSGA having the lowest and HSGD the highest runoff potential, and they have been shown to be valid indicators of watershed vulnerability to herbicide transport (Lerch and Blanchard, 2003). Since runoff potential is critical to surface transport of contaminants, it follows that watersheds or recharge areas dominated by HSGC and D soils would be the most vulnerable to stream contamination. A GIS-based analysis of the intersection of row-crop areas with the HSG, by soil mapping unit, within each recharge area showed that $94 \%$ of the row-crop areas in the Devils Icebox recharge area occurred on HSGD soils compared to only $57 \%$ of the rowcrop areas for Hunters Cave (Fig. 10). Nearly all the row crops on HSGD soils within the Devils Icebox area lie above the losing reach of Bonne Femme Creek. These claypan soils with high runoff potential are known to be especially problematic with respect to surface transport of sediment, nutrients, and herbicides (Lerch and Blanchard, 2003; Lerch et al., 2008).

\section{CONCLUSIONS}

The magnitude and seasonality of contaminant loads in both recharge areas showed that the contaminants were primarily derived from allochthonous sources distributed throughout the recharge areas. Devils Icebox generally had greater concentrations, loads, and fluxes of suspended sediment, nitrogen, phosphorus, and herbicides than Hunters Cave. The greater loads and fluxes at Devils Icebox were due to a combination of greater stream discharge, resulting from differences in recharge-area characteristics, and the extremely high proportion of row crops on claypan soils with high runoff potential. Compared to other agricultural karst recharge areas in the Midwestern US, Devils Icebox and Hunters Cave generally had lower nutrient concentrations and much lower nutrient and herbicide fluxes, but peak concentrations of atrazine, alachlor, and metolachlor were similar to more intensively cropped recharge areas. In both recharge areas, prevailing land management has significantly degraded water quality. Therefore, funding was obtained to develop a stakeholder-led watershed plan for the Bonne Femme watershed (Frueh et al., 2008), with the primary goal of improving water quality. The plan was completed in 2007 and is available on the Web (Bonne Femme Stakeholder Committee, 2007). It has a number of detailed recommendations for karst protection, including limiting stormwater runoff to pre-development levels in karst recharge areas, use of economic incentives to reduce urban development on karst (e.g., transfer of development rights

Journal of Cave and Karst Studies, August 2011•111 
or conservation easements), new zoning regulations to provide special protections to karst recharge areas (e.g., require no-discharge on-site sewer systems), and adoption of a stream-buffer ordinance that limits construction within the 100-year flood plain of all stream channels in the watershed. With the data collected from this study, the impact of implementing these management practices and changes in land use can be documented.

\section{ACKNOWLEDGMENTS}

Thanks to Joe Absheer, Paul Brugman, Scott Matz, and Dr. Lynn Stanley for their technical support in processing and analyzing the samples for this project. Thanks to the Missouri Department of Conservation and Dr. William R. Elliott for permission to access Hunters Cave and install a temporary monitoring station. Thanks to the Missouri Department of Natural Resources, Rock Bridge Memorial State Park staff for permission to access Devils Icebox. Special thanks to Nick Genovese for operation and maintenance of the field equipment.

\section{REFERENCES}

Andreo, B., Goldscheider, N., Iňaki, V., Vias, J.M., Neukum, C., Sinreich, M., Jiménez, P., Brechenmacher, J., Carrasco, F., Hötzl, H., Perles, M.J., and Zwahlen, F., 2006, Karst groundwater protection: First application of a pan-European approach to vulnerability, hazard, and risk mapping in the Sierra de Líbar (Southern Spain): Science of the Total Environment, v. 357 , p. 54-73

Betson, R.P., 1977, The hydrology of karst urban areas, in Dilamarter, R., and Csallany, S., eds., Hydrologic Problems in Karst Regions, Bowling Green, Western Kentucky University, p. 162-175.

Bonne Femme Stakeholder Committee, 2007, Bonne Femme Watershed Plan, http://www.cavewatershed.org/plan.asp.

Booth, D.B., Hartley, D., and Jackson, R., 2002, Forest cover, impervious-surface area, and the mitigation of stormwater impacts: Journal of the American Water Resources Association, v. 38, p. 835-845. DOI: 10.1111/j.1752-1688.2002.tb01000.x.

Boyer, D.G., 2005, Water quality improvement program effectiveness for carbonate aquifers in grazed land watersheds: Journal of the American Water Resources Association, v. 41, p. 291-300. DOI: 10.1111/j.1752-1688.2005.tb03735.x.

Boyer, D.G., and Pasquarell, G.C., 1994, Agricultural land use impacts on karst groundwater quality, in Marston, R.A., and Hasfurther, V.R., eds., Proceedings of the Effects of Human-Induced Changes on Hydrologic Systems Symposium, Jackson Hole, Wyoming, American Water Resources Association Technical Publication Series 94-3, p. 791-799.

Boyer, D.G., and Pasquarell, G.C., 1995, Nitrate concentrations in karst springs in an extensively grazed area: Journal of the American Water Resources Association, v. 31, p. 729-736. DOI: 10.1111/j.17521688.1995.tb03397.x.

Boyer, D.G., and Pasquarell, G.C., 1996, Agricultural land use effects on nitrate concentrations in a mature karst aquifer: Journal of the American Water Resources Association, v. 32, p. 565-573. DOI: 10.1111/j.1752-1688.1996.tb04054.x.

Brakensiek, D.L., Osborn, H.B., and Rawls, W.J., eds., 1979, Field Manual for Research in Agricultural Hydrology: United States Department of Agriculture, Science and Education Administration Agricultural Handbook 224, Revised, 547 p.

Butler, K.S., 1987, Urban growth management and groundwater protection: Austin, TX, in Page, G.W., ed., Planning for Groundwater Protection, New York, Academic Press, p. 261-287.

Crain, A.S., 2006, Concentrations of Nutrients, Pesticides, and Suspended Sediment in the Karst Terrane of the Sinking Creek Basin, Kentucky,
2004: U.S. Geological Survey, Open File Report 2006-1091, http:// pubs.usgs.gov/of/2006/1091/ofr20061091.pdf.

Currens, J.C., 2002, Changes in groundwater quality in a conduitflow-dominated karst aquifer, following BMP implementation: Environmental Geology, v. 42, p. 525-531. DOI: 10.1007/s00254001-0515-6.

Dogwiler, T., Wicks, C.M., and Jenzen, E., 2007, An assessment of the applicability of the heat pulse method toward the determination of infiltration rates in karst losing-stream reaches: Journal of Cave and Karst Studies, v. 69, p. 237-242.

Eisenhauer, J.G., 2003, Regression through the origin: Teaching Statistics, v. 25 , p. 76-80. DOI: 10.1111/1467-9639.00136.

Elliott, W.R., 2000, Conservation of the North American cave and karst biota in Wilkens, H., Culver, D.C., and Humphreys, W.F., eds., Subterranean Ecosystems, Amsterdam, Elsevier, Ecosystems of the World 30, p. 665-689.

Frueh, T., Campbell, R., and Lerch, R.N., 2008, Successful stakeholderled watershed planning, in Elliott, W.R., ed., Proceedings of the $18^{\text {th }}$ National Cave and Karst Management Symposium, NCKMS Steering Committee, p. 144-153.

Gogu, R.C., and Dassargues, A., 2000, Current trends and future challenges in groundwater vulnerability assessment using overlay and index methods: Environmental Geology, v. 39, p. 549-559. DOI: $10.1007 / \mathrm{s} 002540050466$.

Greenberg, A.E., Eaton, A.D., and Clesceri, L.S., eds., 1992, Standard Methods for the Examination of Water and Wastewater, 18th edition, Washington, DC, American Public Health Association, Part 4500, p. 4-80, 4-89, 4-155.

Gulden, B., 2010, US longest caves by state: NSS GEO ${ }^{2}$ Committee on Long and Deep Caves, http://caverbob.com/state.htm [accessed May 7, 2010].

Halihan, T., Wicks, C.M., and Engeln, J.F., 1998, Physical response of a karst basin to flood pulses: Example of the Devil's Icebox cave system (Missouri, USA): Journal of Hydrology, v. 204, p. 24-36.

Hallberg, G.R., Libra, R.D., and Hoyer, B.E., 1985, Nonpoint source contamination of ground water in karst-carbonate aquifers in Iowa, in Perspectives on Nonpoint Source Pollution, Proceedings of a National Conference, Kansas City Mo., Washington, DC, United States Environmental Protection Agency, Criteria and Standards Division, report 440/5-85-001, p. 109-114.

Johnson, G.C., 2002, Water Quality of Springs in the Valley and Ridge Physiographic Province in the Upper Tennessee River Basin, 1997, U.S. Geological Survey, National Water Quality Assessment Program, Water-Resources Investigations Report 02-4180, 24 p.

Katz, B.G., 2004, Sources of nitrate contamination and age of water in large karstic springs of Florida: Environmental Geology, v. 46, p. 689-706. DOI: 10.1007/s00254-004-1061-9.

Katz, B.G., Sepulveda, A.A., and Verdi, R.J., 2009, Estimating nitrogen loading to ground water and assessing vulnerability to nitrate contamination in a large karstic springs basin, Florida: Journal of the American Water Resources Association, v. 45, p. 607-627. DOI: 10.1111/j.1752-1688.2009.00309.x.

Larson, W.E., Pierce, F.J., and Dowdy, R.H., 1983, The threat of soil erosion to long-term crop productivity: Science, v. 219 , p. $458-465$. DOI:10.1126/science.219.4584.458.

Lerch, R.N., Donald, W.W., Li, Y.X., and Alberts, E.E., 1995, Hydroxylated atrazine degradation products in a small Missouri stream: Environmental Science and Technology, v. 29, p. 2759-2768. DOI: $10.1021 / \mathrm{es} 00011 \mathrm{a} 010$.

Lerch, R.N., Erickson, J.M., and Wicks, C.M., 2002, Intensive monitoring in two karst basins of Boone County, Missouri, in Rea, G.T., ed., Proceedings of the $15^{\text {th }}$ National Cave and Karst Management Symposium, United States Department of Agriculture, Colonado National Forest, p. 157-168.

Lerch, R.N., and Blanchard, P.E., 2003, Watershed vulnerability to herbicide transport in northern Missouri and southern Iowa streams: Environmental Science and Technology, v. 37, p. 5518-5527. DOI: 10.1021/es030431s.

Lerch, R.N., Wicks, C.M., and Moss, P.L., 2005, Hydrologic characterization of two karst recharge areas in Boone County, Missouri: Journal of Cave and Karst Studies, v. 67, p. 158-173.

Lerch, R.N., Sadler, E.J., Kitchen, N.R., Sudduth, K.A., Kremer, R.J., Myers, D.B., Baffaut, C., Anderson, S.H., and Lin, C.H., 2008, Overview of the Mark Twain Lake/Salt River Basin conservation 
effects assessment project: Journal of Soil and Water Conservation, v. 63 , p. $345-359$. DOI: $10.2489 /$ jswc. 63.6 .345$.

Loop, C.M., and White, W.B., 2001, A conceptual model for DNAPL transport in karst ground water basins: Ground Water, v. 39, p. 119-127. DOI: 10.1111/j.1745-6584.2001.tb00357.x.

Mahler, B.J., Lynch, L., and Bennett, P.C., 1999, Mobile sediment in an urbanizing karst aquifer: Implications for contaminant transport: Environmental Geology, v. 39, p. 25-38. DOI: 10.1007/ s002540050434.

Missouri Spatial Data Information Service, 2005, Missouri Land Use Land Cover, http://www.msdis.missouri.edu/data/lulc/lulc05.htm [accessed August 11, 2008].

Nydahl, F., 1978, On the peroxodisulphate oxidation of total nitrogen in waters to nitrate: Water Research, v. 12, p. 1123-1130. DOI:10.1016/ 0043-1354(78)90060-X.

Panno, S.V., and Kelly, W.R., 2004, Nitrate and herbicide loading in two groundwater basins of Illinois' sinkhole plain: Journal of Hydrology, v. 290 , p. $229-242$.

Pasquarell, G.C., and Boyer, D.G., 1995, Agricultural impacts on bacterial water quality in karst groundwater: Journal of Environmental Quality, v. 24, p. 959-969. DOI:10.2134/jeq1995.00472425002400050026x.

Pasquarell, G.C., and Boyer, D.G., 1996, Herbicides in karst groundwater in southeast West Virginia: Journal of Environmental Quality, v. 25, p. 755-765. DOI:10.2134/jeq1996.00472425002500040015x.

Pronk, M., Goldscheider, N., and Zopfi, J., 2006, Dynamics and interaction of organic carbon, turbidity and bacteria in a karst aquifer system: Hydrogeology Journal, v. 14, p. 473-484. DOI: 10.1007/s10040-005-0454-5.

Ruhe, R.V., Clark, D.W., and Epstein, M.L., 1980, Urban hydrology in karst and water quality-Inorganic and organic systems, Indiana University at Bloomington Water Resources Research Center, Report of Investigations No. 9, 139 p.

Saxton, K.E., Spomer, R.G., and Kramer, L.A., 1971, Hydrology and erosion of loessial watersheds: Journal of the Hydraulics Division [American Society of Civil Engineers], v. 97, no. 11, p. 1835-1851.

Spanjer, G.R., and Cipollini, M.L., 2006, Relationship between physiochemical factors and distribution of stygobitic crayfishes in southeastern caves: Southeastern Naturalist, v. 5, p. 17-26.

St. Ivany, G., 1988, Geologic and hydrologic characteristics of the GansBonne Femme and Clear Creek watersheds and the Pierpont karst plain near Rock Bridge Memorial State Park, Boone County, Missouri, Missouri Department of Natural Resources, Division of Geology and Land Survey, Open File Report 88-70, 15 p.

Taylor, S.J., Webb, D.W., and Panno, S.V., 2000, Spatial and temporal analyses of the bacterial fauna and water, sediment, and amphipod tissue chemistry within the range of Gammarus acherondytes, Illinois Natural History Survey, Center for Biodiversity. Technical Report 2000(18), $115 \mathrm{p}$.
Thurman, E.M., Goolsby, D.A., Meyer, M.T., and Kolpin, D.W., 1991, Herbicides in surface waters of the Midwestern United States: The effect of the spring flush: Environmental Science and Technology, v. 25 , p. 1794-1796. DOI: 10.1021/es00022a018.

USDA-NASS, 2000-2002, Boone County Planted Area Data for Corn, Sorghum, and Soybean: United States Department of Agriculture, National Agricultural Statistics Service, http://www.nass.usda.gov/ Statistics_by_State/Missouri/index.asp.

USDA-NASS, no date, US Department of Agriculture, National Agricultural Statistics Service Quick Stats, http://www.nass.usda. gov/QuickStats/index.asp [accessed June 23, 2009].

USDA-NRCS, 2001, Soil Survey of Boone County, Missouri, United States Department of Agriculture-Natural Resources Conservation Service, $318 \mathrm{p}$. [makes the author part of this entry agree with the way it's cited in the text. And the publication is dated 2001, not 2002]

USDA-NRCS, 2009, Hydrologic soil groups, chap. 7: United States Department of Agriculture-Natural Resources Conservation Service, Hydrology National Engineering Handbook, Part 630 (H-210_NEH630), $13 \mathrm{p}$.

USEPA, 1996, United State Environmental Protection Agency, Drinking Water Regulations and Health Advisories, $23 \mathrm{p}$.

USEPA, 2002, Implementation guidance for ambient water quality criteria for bacteria: United States Environmental Protection Agency, EPA-823-B-02-003, http://nepis.epa.gov/Exe/ZyPURL.cgi?Dockey= 20003PSB.txt.

Vesper, D.J., Loop, C.M., and White, W.B., 2001, Contaminant transport in karst aquifers: Speleogenesis and Evolution of Karst Aquifers, Theoretical and Applied Karstology, v. 13-14, p. 101-111.

Vesper, D.J., and White, W.B., 2003, Metal transport to karst springs during storm flow: An example from Fort Campbell, Kentucky/ Tennessee, USA: Journal of Hydrology, v. 276, p. 20-36. DOI:10.1016/S0022-1694(03)00023-4.

Wicks, C.M., 1997, Origins of groundwater in a fluviokarst basin: Bonne Femme basin in central Missouri, USA: Hydrogeology Journal, v. 5, p. 89-96. DOI: $10.1007 / \mathrm{s} 100400050124$.

Wicks, C.M., and Engeln, J.F., 1997, Geochemical evolution of a karst stream in Devils Icebox Cave, Missouri, USA: Journal of Hydrology, v. 198, p. 30-41. DOI:10.1016/S0022-1694(96)03328-8.

Wicks, C., Kelley, C., and Peterson, E., 2004, Estrogen in a karstic aquifer: Ground Water, v. 42, p. 384-389. DOI: 10.1111/j.1745-6584.2004. tb02686.x.

Younos, T., Kaurish, F.W., Brown, T., and de Leon, R., 2001, Determining the source of stream contamination in a karst-water system, southwest Virginia, USA: Journal of the American Water Resources Association, v. 37, p. 327-334. DOI: 10.1111/j.1752-1688. 2001.tb00972.x. 